\title{
Antiproliferative effect of a food coloring on colon cancer cell line
}

\author{
Norizadeh Tazehkand M \\ Department of Biotechnology, Institute of Basic and Applied Sciences, Cukurova University, \\ Adana, Turkey. mostafa_noorizadeh@yahoo.com
}

\begin{abstract}
4-MEI (4-Methylimidazole) is used as a chemical intermediate, crude material or component in the manufacture of pharmaceuticals, photographic and photothermographic chemicals, dyes and pigments and agricultural chemicals. 4-MEI is unintentionally found in our food. Caramel colour (which is the most used beverage colouring and food), dark beers and common brands of cola drinks may comprise more than $100 \mu \mathrm{g}$ of this compound per 12-ounce serving. 4-MEl is widely used by people and colon cancer is common in our countries. So, it was decided to do in vitro analysis of anti-cancer effect of 4-MEI by MTT test using htc-116 cell line.

In this study, mouse Htc-116 cell line was treated with 4-MEI concentrations of 300, 450, 600 and $750 \mu \mathrm{g} / \mathrm{mL}$ for 24 hours and 48 hours periods, after that antiproliferative effect of the 4-MEI was studied by MTT assay. In this study $4-\mathrm{MEl}$ at highest concentration of $24 \mathrm{~h}$ and at all concentration for $48 \mathrm{~h}$ treatment time significantly inhibited cell proliferation when it was compared to control. Also, exposing to the 4-MEl for 48 hours led to a decrease in cells proliferation by concentration dependent manner. This result showed that 4-MEl had anticancer effect in htc-116 cells. However, it has to be evaluated with different new studies (Tab. 1, Fig. 4, Ref. 19). Text in PDF www.elis.sk. KEY WORDS: 4-Methylimidazole, Antiproliferative effect, HTC-116 Cell line, MTT assay.
\end{abstract}

\section{Introduction}

4-methylimidazole (4-MEI) a contaminant of caramel colour with known use in certain alcoholic beverages, (Yoshikawa et al, 1981, Klejdus et al, 2006) was newly evaluated by IARC (International Agency for Research on Cancer) in 2011 and set into group 2B (Grosse et al, 2011). The substance was first identified as a tremorogenic and convulsive agent by Nishie et al (1969). LD50 values of 4-MEI are $370 \mathrm{mg} / \mathrm{kg}$ orally and $165 \mathrm{mg} / \mathrm{kg}$ intraperitoneally for mice; $120 \mathrm{mg} / \mathrm{kg}$ intraperitoneally for rabbits; and $590 \mathrm{mg} / \mathrm{kg}$ orally and $210 \mathrm{mg} / \mathrm{kg}$ intraperitoneally for chickens (Nishie et al, 1969).

Food colouring is used both in commercial food production and in household cooking (FDA, 2012). More than 2,500 items of food colouring additives are used for various purposes, including colouring and to increase nutrient value (Toldo, 1999). One of the food colouring is 4-Methylimidazole (4-MEI), which has a yellow colour.

4-MEI is used as a chemical intermediate, crude material or component in the manufacture of pharmaceuticals, photographic and photothermographic chemicals, dyes and pigments and agricultural chemicals (NTP, 2007). 4-MEI is unintentionally found in our foods. Caramel colour (which is the most used beverage colouring in our food), dark beers and common brands of cola drinks may comprise more than $100 \mu \mathrm{g}$ of this compound per 12-ounce serving (Jacobson, 2011).

Department of Biotechnology, Institute of Basic and Applied Sciences, Cukurova University, Adana, Turkey

Address for correspondence: $M$. Norizadeh Tazehkand, Department of Biotechlogy, Institute of Basic and Applied Sciences, Cukurova University, Adana, Turkey
NTP (The National Toxicology Program) reported a two-year consuming cancer assessment of 4-MEI in mice and rats. The result of this research showed a clear evidence of carcinogenic activity of 4-MEI in male and female $\mathrm{B} 6 \mathrm{C} 3 \mathrm{~F} 1$ mice based on increased incidences of alveolar/bronchiolar neoplasms. In accordance with this result, NTP found equivocal evidence of carcinogenic activity in female rats $(\mathrm{F} 344 / \mathrm{N})$ based on increased incidences of mononuclear cell leukaemia and no evidence of carcinogenic activity in male rats. However, the manufacture of certain artificial caramel colourings can lead to the formation of carcinogens (NTP, 2007, Chan et al, 2008). In contrast, other experimental studies reported that 4-MEI provide chemopreventive effects against some types of cancer. The decreased incidences of tumours in rats were mentioned in the NTP results, but they were not given much prominence, because NTP commonly focuses on cytotoxic identification rather than cancer prevention (Chan et al, 2008, Murray, 2011).

According to my knowledge, there are not enough studies regarding protective effect and anticancer effect of the 4MEI, so by considering the extremely usage of the 4-MEI worldwide, it was decided to investigate the protective effect of the substance. 4-MEI is widely used by people and colon cancer is common in our countries. So, it was decided to do in vitro analysis of anti-cancer effect of 4-MEI by MTT test using htc-116 cell line.

\section{Material and method}

\section{Chemicals}

In this research, the test substance (4-MEI) was purchased from Sigma and its properties are shown in Figure 1.

Lot No: 08302BF 
<smiles>Cc1cnc[nH]1</smiles>

Fig. 1. The chemical structure of 4-methylimidazole.

Chemical Formula: $\mathrm{C}_{4} \mathrm{H}_{6} \mathrm{~N}_{2}$

Molecular Weight: 82.11

Synonym: 1H-Imidazole, 4-methyl $(9 \mathrm{Cl})$; imidazole, 4-methyl; 4(5)-methylglyoxaline; 4(5),4(5)-methylimidazole; 5-methylimidazole

Trade name: 4-MEI

Pub Chem : 13195

Molecular weight: $82.10 \mathrm{~g} \mathrm{~mol}^{-1}$

Appearance: Slightly yellowish solid

Density: $1.02 \mathrm{~g} / \mathrm{cm}^{3}$

Melting point: 46 to $48^{\circ} \mathrm{C}\left(115\right.$ to $118{ }^{\circ} \mathrm{F} ; 319$ to $\left.321 \mathrm{~K}\right)$

Boiling point: $263^{\circ} \mathrm{C}\left(505^{\circ} \mathrm{F}\right.$; $\left.536 \mathrm{~K}\right)$

CAS Number: 822-36-6

Purity: $98 \%$

In this study, 4-MEI (CAS Number: 822-36-6, Purity: $98 \%$, Molecular Weight: 82.11) was purchased from Sigma Aldrich and used as a test substance. The molecular structure of the substance is shown in Figure 1. In this research, $\mathrm{pET} 22 \mathrm{~b}$ plasmid was purchased from Novagen and MTT dye (3-(4, 5-dimethylthiazol-2-yl)-2,5-diphenyl tetrazolium bromide), Dimethylsulfoxide (DMSO), htc-116 cell line was purchased from the Sigma and RPMI 1640 medium was purchased from Life technologies.

The htc-116 cells were obtained from Department of Medical Biology, Medicine Faculty of Cukurova University, Adana, Turkey. The culture medium included Dulbecco's RPMI 1640 medium. The cell culture condition was $37{ }^{\circ} \mathrm{C}$ in humidified $5 \%$

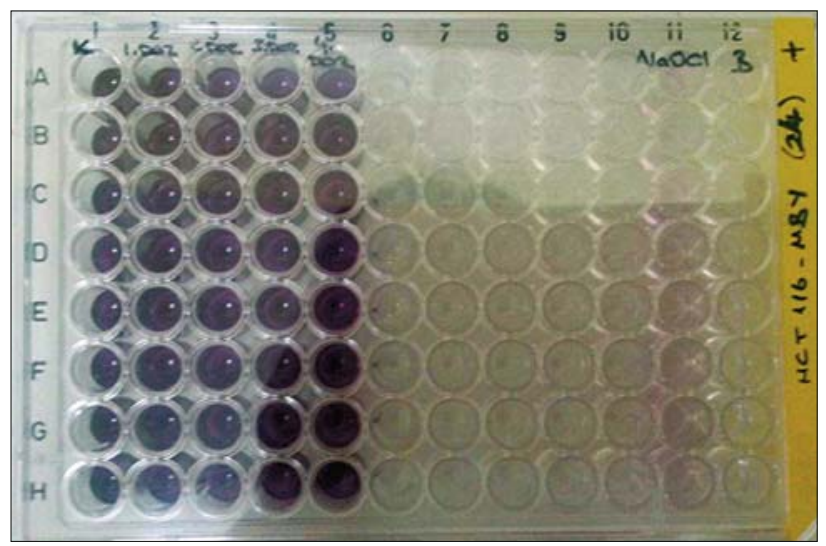

Fig. 2. HTC-116 cells after treatment with 4-MEI and $\mathrm{NaOCl}(24 \mathrm{~h}$ treatment period). 1: untreated control; 2 : htc-116 cells treated with $300 \mu \mathrm{g} / \mathrm{ml}$ of $4-\mathrm{MEI} ; 3:$ htc- 116 cells treated with $450 \mu \mathrm{g} / \mathrm{ml}$ of $4-\mathrm{MEI}$; 4: htc-116 cells treated with $600 \mu \mathrm{g} / \mathrm{ml}$ of 4-MEI; 5: htc-116 cells, 11 : 2: Positive Control ( $\mathrm{NaOCl}$ ): htc-116 cells treated with $500 \mu \mathrm{g} / \mathrm{ml}$ of $\mathrm{NaOCl}$.
$\mathrm{CO}_{2}$ incubator. The inhibition of cell proliferation was evaluated by MTT assay. The MTT assay was performed according to the method from Mosmann (Mosmann, 1983). Htc-116 adipocytes were placed into microtiter plates at a density of $1 \times 10^{4} \mathrm{cells} / \mathrm{well}$. After $24 \mathrm{~h}$, culture medium was replaced by $90 \mu \mathrm{L}$ RPMI 1640 combined with $300,450,600,750 \mu \mathrm{g} / \mathrm{mL}$ of the 4-MEI (The tests for each concentration was repeated 8 times) and the cells were tested in our lab (Norizadeh Tazeh kand et al, 2016). After the incubation time, $10 \mu 1$ sterile filtered MTT solution $(5 \mathrm{mg} / \mathrm{mL})$ in phosphate buffered saline (PBS, $\mathrm{pH}=7.4$ ) was added to each well and the cells were incubated for 5 hours, then unreacted dye was removed. The insoluble formazan crystals were dissolved in $200 \mu \mathrm{L} /$ well DMSO and measured spectrophotometrically in Medispec Esr-200 spectrophotometer at $570 \mathrm{~nm}$ (Sufi et al, 2016, Zhan et al, 2016). The relative cell proliferation (\%) was calculated by equation of:

$\mathrm{A}_{570 \mathrm{~nm}}$ (melanin)/ $\mathrm{A}_{570 \mathrm{~nm}}$ (untreated control) $\times 100$

HTC-116 cells after treatment with 4-MEI and $\mathrm{NaOCl}(24 \mathrm{~h}$ treatment period). 1: untreated control; 2 : htc-116 cells treated with $300 \mu \mathrm{g} / \mathrm{ml}$ of 4-MEI; 3: htc-116 cells treated with $450 \mu \mathrm{g} / \mathrm{ml}$ of 4-MEI; 4: htc-116 cells treated with $600 \mu \mathrm{g} / \mathrm{ml}$ of 4-MEI; 5: htc-

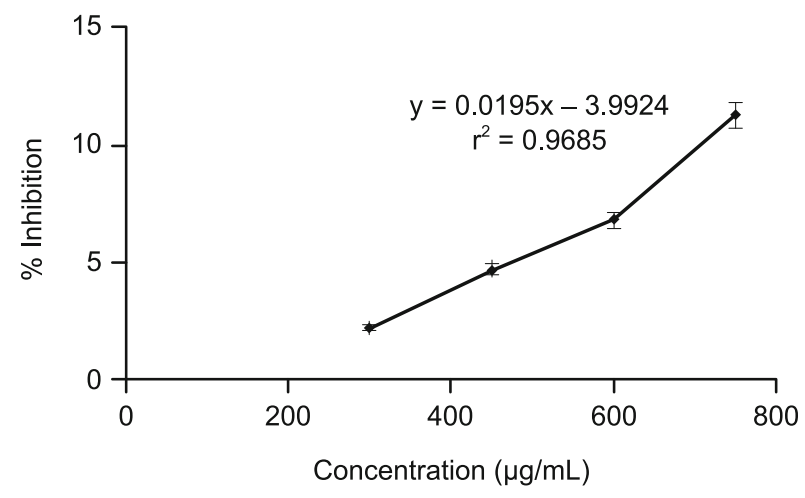

Fig. 3. The cell proliferation inhibition in htc- 116 cell line treated with 4-MEI for $24 \mathrm{~h}$ treatment periods.

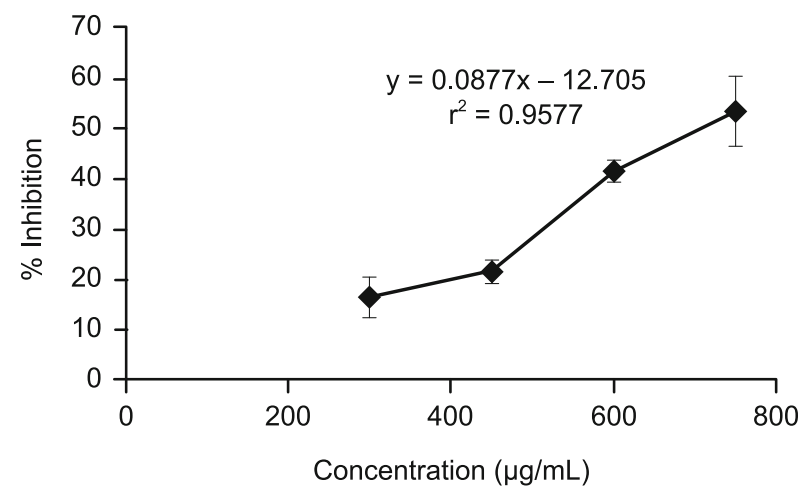

Fig. 4. The cell proliferation inhibition in hte-116 cell line treated with 4-MEI for $48 \mathrm{~h}$ treatment periods. 
Tab. 1. MTT assay of the 4-MEI in htc-116 cell line.

\begin{tabular}{|c|c|c|c|}
\hline \multirow[b]{2}{*}{ Test Substance } & \multicolumn{2}{|c|}{ Treatment } & \multirow[b]{2}{*}{$\begin{array}{l}\text { Mean value } \\
(\%) \pm \mathrm{SE}\end{array}$} \\
\hline & $\begin{array}{l}\text { Time } \\
\text { (hours) }\end{array}$ & $\begin{array}{l}\text { Conc. } \\
(\mu \mathrm{g} / \mathrm{ml})\end{array}$ & \\
\hline Control & 24 & - & $0 \pm 3.82 \mathrm{~b} 3$ \\
\hline $\begin{array}{l}\text { Positive control } \\
(\mathrm{NaOCl})\end{array}$ & 24 & 500 & $95.12 \pm 0.249 \mathrm{a} 3$ \\
\hline 4-MEI & 24 & $\begin{array}{l}300 \\
450 \\
600 \\
750 \\
\end{array}$ & $\begin{array}{c}2.2 \pm 0.249 \\
4.73 \pm 6.13 \mathrm{~b} 3 \\
6.43 \pm 6.88 \mathrm{~b} 3 \\
11.29 \pm 3.249 \mathrm{a} 1 \mathrm{~b} 3\end{array}$ \\
\hline Control & 48 & - & $0 \pm 3.61$ \\
\hline $\begin{array}{l}\text { Positive control } \\
(\mathrm{NaOCl})\end{array}$ & 48 & 500 & $96.073 \pm 0.241$ \\
\hline 4-MEI & 48 & $\begin{array}{l}300 \\
450 \\
600 \\
750\end{array}$ & $\begin{array}{l}16.43 \pm 4.74 \mathrm{a} 2 \mathrm{~b} 3 \\
20.75 \pm 2.30 \mathrm{a} 3 \mathrm{~b} 3 \\
41.73 \pm 2.02 \mathrm{a} 3 \mathrm{~b} 3 \\
53.74 \pm 7.45 \mathrm{a} 3 \mathrm{~b} 3\end{array}$ \\
\hline
\end{tabular}

Data are expressed as the mean values $( \pm \mathrm{SE})$ obtained from 8 repeat; $(n=8)$. A: significant from untreated control; a1b1: $\mathrm{p}<0.05$; $2 \mathrm{~b} 2$ : $\mathrm{p}<0.01 ; \mathrm{a} 3 \mathrm{~b} 3$ : $\mathrm{p}<0.001$

116 cells, 11: 2: Positive Control ( $\mathrm{NaOCl})$ : htc-116 cells treated with $500 \mu \mathrm{g} / \mathrm{ml}$ of $\mathrm{NaOCl}$ (Fig. 2).

\section{Statistical analysis}

Data were presented as the means $\pm \mathrm{SD}$. Statistical analysis was performed using Student's t-test. In this research, statistical tests were performed using Minitab software (Norizadeh Tazehkand and Topaktas, 2015).

\section{Result and discussion}

In order to do MTT assay, the cells were treated with different concentrations of the 4-MEI $(300,450,600$ and $750 \mu \mathrm{g} / \mathrm{ml})$ and incubated for 24 and 48 hours (Figs 3 and 4). After that, cell concentration was assayed by spectrophotometer $\left(\mathrm{OD}_{570}\right)$ and subjected to calculation of relative cell concentration. The antiproliferative effect of 4-MEI on htc-116 cell line is shown in Table 1. In this study, 4-MEI at the highest concentration of $24 \mathrm{~h}$ and at all concentration for $48 \mathrm{~h}$ treatment time significantly inhibited cell proliferation, when it was compared to the control. In this study, treatment of htc-116 cell line by 4-MEI for $24 \mathrm{~h}$ showed a decreased cell proliferation up to $2.2 \%, 4.73 \%, 6.43 \%$ and 11.29 $\%$ by concentration of $300 \mu \mathrm{g} / \mathrm{ml}, 450 \mu \mathrm{g} / \mathrm{ml}, 600 \mu \mathrm{g} / \mathrm{ml}$ and 750 $\mu \mathrm{g} / \mathrm{ml}$ respectively. Also, for 48 hour exhibited $16.43 \%, 20.75 \%$, $41.73 \%$ and $53.74 \%$ by concentrations of $300 \mu \mathrm{g} / \mathrm{ml}, 450 \mu \mathrm{g} /$ $\mathrm{ml}, 600 \mu \mathrm{g} / \mathrm{ml}$ and $750 \mu \mathrm{g} / \mathrm{ml}$ respectively. In the positive control group that was treated with $\mathrm{NaOCl}$, the decrement was $95.12 \%$. Also, exposing to the 4-MEI for 48 hours led to a decrease in cells proliferation by concentration dependent manner.

\section{Discussion}

According to our knowledge, this is the first study that addresses the anticancer potential of 4-MEI in htc-116 cell line. In this research, the MTT assay was carried out to measure the cytotoxicity.
The assay showed that 4-MEI at highest concentration of $24 \mathrm{~h}$ and at all concentration for $48 \mathrm{~h}$ treatment time significantly inhibited cell proliferation of htc-116 cell line. The result of this study showed that 4-MEI has anticancer effect on cells.

Rayes et al (2008) showed that cola had anti-bacterial effect on Bifidobacterium bifidum and Lactobacillus acidophilus. Also, it had cytotoxic effect on Mouse testis cells. Cola drinks may contain more than $100 \mu \mathrm{g}$ of this compound per 12-ounce serving (Jacobson and Michael, 2011). Murray (20110 in his paper from National Toxicology Program (NTP) reported that 4-MEI had anticancer effect on fibroadenoma. In the paper published by Takemoto (2002) it was written that the 4-MEI has antibacterial and antifungal effect because it made the bacterial and fungal plasma membrane to be permeable, which causes the cell death. Similarly, Liver hypertrophy in mice following intraperitoneal administration of 4-methylimidazole has been reported by Hidaka et al (1976). In hypertrophy, the cell volume is increased because of the absorbance of more food or water.

This result showed that 4-MEI has anticancer effect in htc-116 cells. However, it must be evaluated with different new studies.

\section{References}

1. Chan P C, Hill GD, Kissling GE, Nyska A. Toxicity and carcinogenicity studies of 4-methylimidazole in F344/N rats and B6C3F1 mice. Arch Toxicol 2008; 82: 45-53.

2. FDA. CFR Title 21 Part 70: Color Additive Regulations, retrieved Feb., $2012,15$.

3. Grosse Y, Baan R, Secretan-Lauby B, El Ghissassi F, Bouvard V, Benbrahim-Tallaa L, Guha N, Islami F, Galichet L, Straif K. Carcinogenicity of chemicals in industrial and consumer products, food contaminants and flavourings, and water chlorination byproducts. Lancet Oncol 2011; 12: 328-329.

4. Hidaka M. Physiological agency of 4-methylimidazole. Part 3. Absorbance and excretion rate of 4-methylimidazole in the organ. Okayama Igakkai Zasshi 1976; 88: 665-671, 673-680.

5. Jacobson M.F., Petition to Bar the Use of Caramel Colorings Produced With Ammonia and Containing the Carcinogens 2-Methylimidazole and 4-Methylimidazole. Center Sci Publ Interest 2011; 1-11.

6. Jacobson MF, Michael F. Petition to bar the use of caramel colorings produced with ammonia and containing the carcinogens 2-methylimidazole and 4-methylimidazole. Center for Science in the Public Interest Available at: http://cspinet org/new/pdf/caramel_coloring_petition pdf 2011.

7. Klejdus B, Moravcova J, Lojkova L, Vacek J, Kuban V. Solid phase extraction of 4(5)- methylimidazole (4MeI) and 2-acetyl-4(5)-(1,2,3,4tetrahydroxybutyl)-imidazole (THI) from foods and beverages with subsequent liquid chromatographic electrospray mass spectrometric quantification. J Sep Sci 2006; 29: 378-384.

8. Mosmann T. Rapid colorimetric assay for cellular growth and survival: application to proliferation and cytotoxicity assays. J Immunol Methods, 1983; 65: 55-63.

9. Murray FJ. Does 4-methylimidazole have tumor preventive activity in the rat? Food Chem Toxicol 2011; 49: 320-322. 


\section{5-268}

10. National Toxicology Program (NTP)., NTP Technical Report on the Toxicology and Carcinogenesis Studies of 4-Methylimidazole (CAS No. 822-36-6) in F344/N Rats and B6C3F1 Mic NTP TR-535. Research Triangle Park., NC. 2007.

11. Nishie K, Waiss AC Jr, Keyl AC. Toxicity of methylimidazoles. Toxicol Aool Pharmacol 1969; 14: 303-307.

12. Norizadeh Tazehkand M, Topaktas M. The in vitro genotoxic and cytotoxic effects of remeron on human peripheral blood lymphocytes. Drug Chem Toxicol 2015; 38 (3): 266-271.

13. Rayes AAH. Effect of Some Drinks on the Benificial Probiotic Bacteria and the Structure of Testis of Male Albino Mice. J Appl Sci Res 2008; 4 (7): 803-813,

14. Sufi SA, Adigopula LN, Syed SB, Mukherjee V, Coumar MS, Rao HS, Rajagopalan R. In-silico and in-vitro anti-cancer potential of a curcumin analogue (1E, 6E)-1,7-di(1H-indol-3-yl)hepta-1,6-diene-3,5-dione. Biomed Pharmacother 2016; Nov 23. S0753-3322(16)31272-0.
15. Takemoto M, Sun J, Hiroki J, Shimokawa H, Liao JK. Rho-kinase mediates hypoxia-induced downregulation of endothelial nitric oxide synthase. Circulation 2002; 106 (1): 57-62.

16. Tazehkand MN, Moridikia A, Hajipour O, Valipour E, Timocin T, Topaktas M, Yilmaz MB. The effects of 4-MEI on cell proliferation, DNA breaking and DNA fragmentation. Bratisl Lek Listy 2016; 117 (7): 371-375.

17. Toledo MF. Regulamentacao de Uso de Corantes Naturais. Arch Latinoam Nutr 1999; 49: 67-70.

18. Yoshikawa S, Fujiwara M. Determination of 4(5)-methylimidazole in food by thin layer chromatography. J Food Hyg Soc Jap 1981; 22: 189-196.

19. Zhan W, Liao X, Yu L, Tian T, Liu X, Liu J, Cai LJ, Xiao X, Xie RJ, Yang Q. Effects of blueberries on migration, invasion, proliferation, the cell cycle and apoptosis in hepatocellular carcinoma cells. Biomed Rep 2016; 5 (5): 579-584. 